\title{
The Influence of Exchange Rate, World Oil Price, and BI Rate on Airline Companie's Return in Indonesian Stock Market
}

\author{
Yonatan Alvin Stefan ${ }^{1}$, Robiyanto Robiyanto ${ }^{2}$ \\ 1,2,Fakultas Ekonomika dan Bisnis Universitas Kristen Satya Wacana Salatiga
}

\section{A R T I C L E I N F O}

Article history:

Received 19 May 2019

Received in revised form

16 June 2019

Accepted 15 July 2019

Available online 30 August 2019

Keywords:

Airline Sector, Exchange

Rate, World Oil Price,

BI Rate, GARCH

\begin{abstract}
A B S T R A C T
In an effort to support the economic growth of Indonesia, an infrastructure development is carried out to achieve the national development. It brings positive influences on transportation companies in Indonesia. Many companies list their shares to Indonesia Stock Exchange, including PT. Garuda Indonesia (Persero) Tbk (IDX code: GIAA) and PT. AirAsia Indonesia Tbk (IDX code: CMPP), aiming to have additional capital sources. The two companies can be such a reference for investors to make investments, but they still need to consider the macro factors attached. This study examines the influende of exchange rate, world oil price, and Bank Indonesia $(\mathrm{BI})$ rates on the GIAA and CMPP stock returns. The analysis technique used was Generalize Autoregressive Conditional Heteroscedasticity (GARCH) and daily data starting from their IPO to February 28th, 2019. The results showed that the exchange rate negatively affected the GIAA and CMPP stock returns, while the world oil prices only negatively affected the CMPP stock return, and the $\mathrm{BI}$ rates only negatively affected the GIAA stock return. In general, the investors are suggested not to buy the GIAA and CMPP shares when the IDR exchange rate weakens against the US dollar exchange rate.
\end{abstract}

\footnotetext{
* Corresponding author.

E-mail addresses: alvinstevanyo2@gmail.com (Yonatan Alvin Stefan)
} 


\section{Introduction}

In this globalization era, investment in the capital market is getting bigger. Budiman (2017) said that Indonesia is so large and there are still many under-developed areas, making it difficult to grow optimally with its existing potential. Therefore, this growth needs to be supported by investment activities, both from domestic and foreign investors. Therefore, the growth of the Indonesian economy will also be accompanied by the growth of the Indonesian capital market in the future.

It was recorded that as of in early 2019, there were 622 companies listed on the Indonesia Stock Market (IDX) consisting of companies engaged in industries of agriculture, mining, basic industries and chemicals, consumer goods, property, real estate, building construction, transportation, infrastructure, utilities, trading, services, investment and finance. In the era of President Joko Widodo, the government recently formed a classification of infrastructure budget as a certain budget item in the State Budget (AnggaranPendapatandaanBelanja Negara (APBN) in Bahasa) to focus on the national development to support the economic growth. The infrastructure development starts from the construction of toll roads, sea tolls, ports, and airports to accelerate the distribution of goods and services across the islands in Indonesia. The development of the transportation company industry in Indonesia has a growth rate of 9.5\% in 2017 for domestic and international passengers based on a data from the Directorate General Air Transportation Ministry of Transportation. Therefore, it can be concluded that their performance has a positive trend.

In an effort to support the positive performance of airline companies in Indonesia, there are two airline companies that are looking for additional capital on the IDX and achieved by the company that is Good Corporate Gorvenance (GCG) through financial report transparency. PT. Garuda Indonesia (Persero) Tbk (IDX code: GIAA) is an airline company of State-Owned Enterprises (Badan Usaha Milik Negara (BUMN) in Bahasa)which had itsinitial public offering (IPO) on February 11 ${ }^{\text {th }}, 2011$ with the first price offered of IDR 750.00 per share (www.rti.co.id). They aimed to increase their economic growth and competitiveness, strengthen financial fundamentals, and realize the GCG (www.okezone.com). In addition, PT. AirAsia Indonesia Tbk (IDX code: CMPP) entered the stock market through a backdoor listing scheme (a non-open company process to enter the stock exchange by acquiring a publicly listed company or listed on the stock exchange) through PT. Rimau Multi Putra Pratama Tbk. After the transaction, the company changed its name to PT. AirAsia Indonesia Tbk on January 3rd, 2017 (www.kompas.com). They also issued new shares at an implementation price of IDR 250.00 per share (m.detik.com). The CEO of AirAsia Indonesia, Mr. Darmadi, stated that the purpose of this IPO was to buy new aircrafts, get operational capital, and increase working capital (www.kontan.co.id)

The existence of GIAA and CMPP on the IDX can be such a reference for investors. An investor will certainly choose a company that will provide high stock returns, one of which is seen from the company's performance (Sukamulja, 2017).Besides, risk considerations are also important.Therefore,the investors need to pay attention to the micro and macro factors of the company. The micro factors refer to the internal factors of the company that affect stock trading transactions, including stock prices, level of profits obtained, risk level, company performance, and corporate action carried out by the company.Meanwhile, the macro factors refer to the external factors of the company, including the inflation development of the IDR exchange rate, world oil price, and the state of the economy and the socio-political conditions of the country.

In this study, the researchers focus on the macro factors influencing the stock returns which consist of the exchange rate, world oil price, and Bank Indonesia (BI) rate. Gumilang, Hidayat and NP (2014) had found that these factors simultaneously influenced the Jakarta Composite Index (JCI) in the period of 2009-2013.Therefore, researchers try to re-examine the same independent variables, but focus on the stock return of the airline companies listed on the IDX for there are only few researches focusing on the research object.

Based on the description above, there are severalresearch questions that can be formulated: 1) How does exchange rate influence the stock return of GIAA and CMPP; 2) How does world oil price influence the stock return of GIAA and CMPP?; and 3) How does BI rate influence the stock return of GIAA and CMPP? 


\section{Methods}

\section{A. Type and Sources of Data}

This study useda secondary data.The daily exchange rates of USD/ IDR and BI rate were obtained from the official website of Bank Indonesia (www.bi.go.id), the daily world oil price data was obtained from www.investing.com, and the GIAA and CMPP's daily stock prices were obtained from www.finance.yahoo.com.

\section{B. Population and Sample}

The population of this study were all air transportation companies listed on the Indonesia Stock Exchange (IDX), starting from February $28^{\text {th }}, 2019$ which included PT. Garuda Indonesia (Persero) Tbk (IDX code: GIAA) and PT. AirAsia Indonesia Tbk (IDX code: CMPP). There were only two companies, thus they were also used as the samples and their IPO dates were also different.

\section{Definition of Operational Variables}

In this study, the dependent variable was the stock return of GIAA and CMPP and it can be calculated from the closing price of the shares on a daily basis. The formula is as follows:

Notes:

$$
R t=\frac{P(t)-P(t-1)}{P(t-1)} \times 100 \%
$$

$\mathrm{Rt} \quad=$ Return of stock price in $\mathrm{t}$ period(in percent)

$\mathrm{P}(\mathrm{t}) \quad=$ Stock price in $\mathrm{t}$ period (in Rupiah (IDR))

$\mathrm{P}(\mathrm{t}-1)=$ Stock price index in $\mathrm{t}-1$ period (in Rupiah (IDR))

On the other hand, the independent variables included exchange rate, BI rate, and world oil price. They can be calculated using the following formulas:

Notes:

$$
E R=\frac{E R(t)-E R(t-1)}{E R(t-1)} \times 100 \%
$$

ER = The change of exchange rate (in percent)

$\mathrm{ER}(\mathrm{t})=$ The exchange rate in $\mathrm{t}$ period (in Rupiah (IDR))

$\mathrm{ER}(\mathrm{t}-1)=$ The exchange rate in $\mathrm{t}-1$ period (in Rupiah (IDR))

$$
B I=\frac{B I(t)-B I(t-1)}{B I(t-1)} x 100 \%
$$

Notes:

$\begin{array}{ll}\mathrm{BI} & =\text { The change of } \mathrm{BI} \text { rate (in percent) } \\ \mathrm{BI}(\mathrm{t}) & =\mathrm{BI} \text { rate in } \mathrm{t} \text { period (in Rupiah (IDR)) } \\ \mathrm{BI}(\mathrm{t}-1) & =\mathrm{BI} \text { rate in } \mathrm{t}-1 \text { period (in Rupiah (IDR)) }\end{array}$

Notes:

WTI = The change of world oil price (in percent)

$\mathrm{WTI}(\mathrm{t})=$ The world oil price in $\mathrm{t}$ period (in Rupiah (IDR))

WTI(t-1) $=$ The world oil price in $\mathrm{t}-1$ period (in Rupiah (IDR))

\section{Data Analysis}

The Generalized Autoregressive Heteroscedasticiy (GARCH) method was developed by Bollerslev (1986) where the initial model was called Autoregressive Heteroscedasticiy (ARCH). At GARCH equations, conditional variants change during periods as a function of past errors and past conditional variants.Besides, the constant values in $\beta 1$ and $\alpha 1$ must be positive or non-negative in the GARCH process (Bollerslev, 1986) to ensure that all $\sigma_{-} t^{\wedge} 2$ is non-negative. This method is very popular in the financial world. Sung (1991) examined the stock returns and volatility of the Tokyo Stock Exchange and also used this method. 
The following is the research model:

$\mathrm{Ri}=\alpha+\beta_{1}(\mathrm{CO})+\beta_{2}(\mathrm{ER})+\beta_{3}(\mathrm{BIR})+\mathrm{e}$

where

$\varepsilon \mathrm{t}=\Phi \mathrm{t} \varepsilon \mathrm{t}-1+\ldots+\Phi \mathrm{t} \varepsilon \mathrm{t}-\mathrm{p}+\eta \mathrm{t}$

$\eta \mathrm{t}=\sigma \mathrm{t} \varepsilon \mathrm{t}$

Notes:

$\sigma 2 t=\alpha 0+\alpha 1 \eta 2 t-1+. .+\alpha p \eta 2 t-p+\beta 1 \sigma 2 t-1+\ldots+\beta q \sigma 2 t-q$

$\mathrm{Ri} \quad=$ Stock return of GIAA and CMPP

$\mathrm{CO}=$ World oil price

$\mathrm{ER}=$ Exchange rate's change

$\mathrm{BIR}=\mathrm{BI}$ Rate

$\mathrm{e}=$ error

\section{Result and Discussion}

\section{A. Descriptive Statistics}

Table 1. Descriptive Statistics of GIAA Stock Returns, Exchange Rate, World Oil Price and BI Rate

\begin{tabular}{lccccc}
\hline \multicolumn{1}{c}{ Variables } & N & Minimum & Maximum & Mean & Std. Dev. \\
\hline GIAA_RETURN & 1950 & -0.087719 & 0.19 & 0.000202 & -0.087719 \\
EXCHANGE_RATE & 1950 & -0.028149 & 0.027476 & 0.000243 & 0.004338 \\
WORLD_OIL_PRICE & 1950 & -0.090607 & 0.135084 & 0.000241 & 0.021003 \\
BI_RATE & 1950 & -0.090607 & 0.135084 & 0.000241 & 0.021003 \\
\hline
\end{tabular}

Source: Secondary data, processed.

Table 1. presents the results of descriptive statistic of GIAA stockreturn, exchange rate, world oil price, and BI rate on January $11^{\text {th }}, 2011$ - February 28 $8^{\text {th }}, 2019$. The highest return of GIAA is on November $15^{\text {th }}, 2018$, and the lowest is on February 22nd 2011.

Table 2. Descriptive Statistics of CMPP Stock Returns, Exchange Rate, World Oil Price and BI Rate

\begin{tabular}{lccccc}
\hline \multicolumn{1}{c}{ Variables } & N & Minimum & Maximum & Mean & Std. Dev. \\
\hline CMPP_RETURN & 522 & -0.249997 & 0.348151 & 0.003753 & 0.069325 \\
EXCHANGE_RATE & 522 & -0.017073 & 0.013523 & 0.0000923 & 0.003172 \\
WORLD_OIL_PRICE & 522 & -0.072702 & 0.076718 & 0.000486 & 0.017718 \\
BI_RATE & 522 & -0.216688 & 0.241135 & 0.000985 & 0.024447 \\
\hline
\end{tabular}

Table 2. presents the results of descriptive statistics of CMPP stockreturns, exchange rate, world oil price and BI rate on January $3^{\text {rd }}, 2017$ - February 28 $8^{\text {th }}, 2019$. The highest return of GIAA is on August $15^{\text {th }}$, 2017 and the lowest is on September 28 ${ }^{\text {th }}, 2017$.Unit Root Test

Table 3. Results of Unit RootTest of GIAA Stock Returns, Exchange Rate, World Oil Price and BI Rate

\begin{tabular}{lccc}
\hline Variables & t-statistic & Probability & Result \\
\hline GIAA_RETURN & -45.41509 & 0.0001 & Stasionary \\
EXCHANGE_RATE & -43.71472 & 0.0001 & Stasionary \\
WORLD_OIL_PRICE & -47.31416 & 0.0001 & Stasionary \\
BI_RATE & -32.36754 & 0.0000 & Stasionary \\
\hline
\end{tabular}

Table 4. Results of Unit Root Test of CMPP Stock Returns, Exchange Rate, World Oil Price and BI Rate

\begin{tabular}{lccc}
\hline \multicolumn{1}{c}{ Variables } & t-statistic & Probability & Result \\
\hline CMPP_RETURN & -15.60160 & 0.0000 & Stasionary \\
EXCHANGE_RATE & -21.05419 & 0.0000 & Stasionary \\
WORLD_OIL_PRICE & -24.19681 & 0.0000 & Stasionary
\end{tabular}


The unit roottest in this study used Augmented Dickey Fuller (ADF) test. This can be seen in Table 3.and Table 4.whichshow that there is no unit root and the data is stationary. Therefore, the data can be analyzed using the GARCH method.

\section{Results of GARCH Method Analysis (1,1)}

Table 5. Results of GARCH $(1,1)$ of GIAA Stock Returns, Exchange Rate, World Oil Price and BI

\begin{tabular}{ccccc}
\hline Variable & Coefficient & Std. Error & z-Statistic & Prob. \\
\hline C & -0.000346 & 0.000317 & -1.092914 & 0.2744 \\
EXCHANGE_RATE & -0.498807 & 0.084772 & -5.884094 & 0.0000 \\
WORLD_OIL_PRICE & -0.022655 & 0.015566 & -1.455418 & 0.1456 \\
BI_RATE & 0.038536 & 0.021182 & 1.819325 & 0.0689
\end{tabular}

Variance Equation

\begin{tabular}{|c|c|c|c|c|}
\hline $\begin{array}{c}\mathrm{C} \\
\operatorname{RESID}(-1)^{\wedge} 2 \\
\operatorname{GARCH}(-1)\end{array}$ & $\begin{array}{l}1.83 \mathrm{E}-05 \\
0.274226 \\
0.741791\end{array}$ & $\begin{array}{l}2.43 E-06 \\
0.016654 \\
0.011776\end{array}$ & $\begin{array}{l}7.547745 \\
16.46575 \\
62.98998\end{array}$ & $\begin{array}{l}0.0000 \\
0.0000 \\
0.0000\end{array}$ \\
\hline $\begin{array}{l}\text { R-squared } \\
\text { Adjusted R-squared } \\
\text { S.E. of regression } \\
\text { Sum squared resid } \\
\text { Log likelihood } \\
\text { Durbin-Watson stat }\end{array}$ & $\begin{array}{l}0.011233 \\
0.009709 \\
0.023083 \\
1.036884 \\
4842.748 \\
2.056546\end{array}$ & $\begin{array}{r}\text { Mean de } \\
\text { S.D. dep } \\
\text { Akaike ir } \\
\text { Schwar } \\
\text { Hannan- }\end{array}$ & $\begin{array}{l}\text { dent var } \\
\text { lent var } \\
\text { criterion } \\
\text { iterion } \\
\text { nn criter. }\end{array}$ & $\begin{array}{c}0.000202 \\
0.023196 \\
-4.959742 \\
-4.939727 \\
-4.952383\end{array}$ \\
\hline
\end{tabular}

Based on Table 5., it can be seen that one of three hypotheses can be supported which is the first hypothesis. It explains that the exchange rate has a negative effecton the stock return of GIAA with a $1 \%$ significance level.However, the world oil price is not significant to GIAA stock returns with a significance level of $10 \%$, and BI rate has empirically proven that it has a positive effect on GIAA stock returns with a significance level of $5 \%$. The GARCH probability shows a significant number at 0.0000 , so that it can follow the GARCH $(1,1)$ pattern.

Table 6. Results of GARCH $(1,1)$ of CMPP Stock Returns, Exchange Rate, World Oil Price and BI Rate

\begin{tabular}{lcccc}
\hline \multicolumn{1}{c}{ Variable } & Coefficient & Std. Error & z-Statistic & Prob. \\
\hline C & & & & \\
EXCHANGE_RATE & -0.005960 & 0.001429 & -4.170292 & 0.0000 \\
WORLD_OIL_PRICE & -1.133827 & 0.470492 & -2.409878 & 0.0160 \\
BI_RATE & -0.161066 & 0.079186 & -2.034025 & 0.0419 \\
& 0.099431 & 0.085113 & 1.168216 & 0.2427 \\
\hline
\end{tabular}

Variance Equation

\begin{tabular}{lllll}
\hline & & & & \\
C & 0.001095 & $5.90 \mathrm{E}-05$ & 18.56780 & 0.0000 \\
$\operatorname{RESID}(-1)^{\wedge} 2$ & 0.922901 & 0.110208 & 8.374160 & 0.0000 \\
GARCH(-1) & 0.051358 & 0.022561 & 2.276472 & 0.0228
\end{tabular}

$\begin{array}{llcl}\text { R-squared } & -0.013243 & \text { Mean dependent var } & 0.003753 \\ \text { Adjusted R-squared } & -0.019111 & \text { S.D. dependent var } & 0.069325\end{array}$




\begin{tabular}{llcl} 
S.E. of regression & 0.069985 & Akaike info criterion & -3.167905 \\
Sum squared resid & 2.537085 & Schwarz criterion & -3.110810 \\
Log likelihood & 833.8232 & Hannan-Quinn criter. & -3.145542 \\
Durbin-Watson stat & 1.261959 & & \\
\hline
\end{tabular}

Based on Table 6., it can be seen that two of the three hypotheses can be supported. They are the first and second hypothesis which explain the exchange rate negatively affect the return of CMPP with a significance level of $1 \%$, while the world oil price has a negative effect on CMPP stock returns with a significance level of 5\%, and BI rate is not significant to the CMPP stock returns with a significance level of $10 \%$. The GARCH probability shows a significant number at 0.0228 , so that it can follow the GARCH $(1,1)$ pattern.

Based on the hypotheses developed, not all of them can be supported and there is a difference in supporting or rejecting the hypothesis in GIAA and CMPP cases. In the first hypothesis, the exchange rate has a negative effect on GIAA and CMPP returns because the investors would tend to switch to investing in USD when the prices were high and they would sell the GIAA and CMPP shares. It would lead to a decrease in the prices of both shares. In the second hypothesis, there is a difference in supporting the hypothesis, where at the GIAA, it is found that changes in world oil prices are not significant to the GIAA stock returns because the data were converted in USD / IDR exchange rates on the same date procurement of the GIAA fuel from PT. Pertamina (Persero) whose transactions used IDR currency. Therefore, it did not affect each other and different results are found with the CMPP case where changes in world oil prices have a negative effect on the stock return. This happens because the CMPP wascentered at Kuala Lumpur International Airport, Malaysia.The fuel procurement did not use IDR currency in the transaction process, so that there were differences in the currency and exchange rates used. This influenced the financial statements which were one of the fundamental analysis tools for investors, because there were additional operational costs due to the increase in world oil prices which further, it wouldaffect the net income and cause them to be less interested in investing in CMPP shares. On the other hand, the second and the third hypothesis also produce different results. The GIAA return is negatively affected by changes in BI rate, because of the use of GIAA loans that used the BI rate reference and the company waslocatedin Indonesia. Therefor, the impact of higher loan interest rates would reduce the GIAA net profit, because GIAA must bear the burden of higher loan interest rates and simultaneously could affect the return of GIAA shares. This made the investors to be hesitant to invest, because the company's net income had declined due to the high BI rate. It was different from the CMPP whose centerwas not in Indonesia and the loan interest did not use BI rate, making the changes did not affect the CMPP stock return.

In this study, the result of the first hypothesis is in line with several previous researches such asRobiyanto (2018), Kewal (2012), Astuti, Susanta andApriatni (2013) and Gumilang et al. (2014), and also Mardiyati(2013) who found that the exchange rate had a negative influence on stocks.The second hypothesis is supported by Gumilang, Hidayatand NP (2014), Faf (2008), Rattib (2009), Aloui (2010) and George Filis (2011) who also found that world oil price had a negative effect on stock returns. The last hypothesis result is supported by Robiyanto (2018), Utami (1997), Budiantara (2012), Astuti et al. (2013), and Ardana (2016) who also found that BI rate had a negative effect on stocks.

\section{Conclusion}

Based on the results, it can be concluded that: 1) The exchange rate has a negative effect on the stock returns of airline companies, both on GIAA and CMPP stock returns. 2) The world oil price has a negative effect on the CIMP stock return of , while it had no significant effect on the GIAA stock return. 3) BI rate has a negative effect on the GIAA stock return of, while it had no significant effect on theCMPP stock return.

Then, the investors are suggested not to buy shares of airlines companies when the IDR exchange rate weakens against than the USD exchange rate. It is because the effect is negative on its stock returns. Future researchesmay develop other independent variables such as market risk, the level of per capita income, number of Indonesian foreign tourists, Gross National Product (PendapatanNasionalBruto(PNB) in Bahasa)to examine the influence of stock returns of airline companies listed on the IDX 


\section{Reference}

Aloui, R. J. (2010). Wavelet decomposition and regime shifts: Assessing the effects of crude oil shocks on stock market returns. Energy Policy, Volume 38, Issue 3, 1415-1435.

Ardana, Y. (2016). PengaruhVariabelMakroekonomiterhadapIndeksSahamSyariah di Indonesia: Model ECM. Esensi, 6(1), 17-30. https://doi.org/10.15408/ess.v6i1.3118

Astuti, R., Susanta, H., \&Apriatni. (2013). AnalisisPengaruh Tingkat SukuBunga( SBI ), NilaiTukar ( Kurs ) Rupiah , Inflasi , Dan Indeks Bursa InternasionalTerhadapIhsg. Diponegoro Journal of Social and Politic of Science, 2(4), 1-10.

Budiantara, M. (2012). Pengaruh Tingkat SukuBunga, NilaiKurs, danInflasiterhadapIndeksHargaSahamGabungan di Bursa Efek Indonesia PeriodeTahun 2005-2010. JurnalSosiohumaniora, 3(3), 57-66.

Budiman, R. (2017). Investing is Easy. Jakarta: PT. Elex Media Komputindo.

Bollerslev. (1986). Generalized Autoregressive Conditional Heteroscedasticity. Journal of Econometrics 31 Vol, 307-327.

Faf, M. N. (2008). Does oil move equity prices? A global view. Energy Economics, Vol 30, Issue 3, 986-997.

George Filis, S. s. (2011). Dynamic correlation between stock market and oil prices: The case of oilimporting and oil-exporting countries. International Review of Financial Analysis, Volume 20, Issue $3,152-164$.

Gumilang, R. C., Hidayat, R. R., \& NP, M. G. W. E. (2014). PengaruhVariabelMakroEkonomi, HargaEmasdanHargaMInyakduniaTerhadapIndeksHargaSahamGabungan (Studipada Bursa Efek Indonesia Periode 2009-2013). JurnalAdministrasiBisnis (JAB), 14(2), 1-9.

Handiani, S. (2014). PengaruhHargaEmasDunia, HargaMinyakDuniadanNilaiTukarDolar, 1(1), 85-93.

Kewal, S. S. (2012). PengaruhInflasi, SukuBunga, Kurs, Dan Pertumbuhan PDB $\begin{array}{lll}\text { TerhadapIndeksHargaSahamGabungan. JurnalEconomia, } & \text { 8(i), }\end{array}$ https://doi.org/http://dx.doi.org/10.21831/economia.v8i1.801

Mardiyati, U. (2013). StudiKasusPada Perusahaan Properti yang Terdaftar di Bursa Efek Indonesia. JurnalRisetManajemen, 4(1), 1-15.

Nabhani, Ahmad. (2014). Melempem, SahamSektorPenerbangan - KURANG PEMINAT IPO $\begin{array}{llll}\text { GARUDA?.Diaksespadatanggal } & 13 & \text { Februari } & 2019\end{array}$ padahttp://www.neraca.co.id/article/38706/melempem-saham-sektor-penerbangan-kurangpeminat-ipo-garuda

Nicholas Sima, H. Z. (2015). Oil prices, US stock return, and the dependence between their quantiles. Journal of Banking \& Finance, Vol 55, 1-8.

Robiyanto, R. (2018). The Effect of Gold Price Changes, USD/IDR Exchange Rate Change and Bank Indonesia (BI) Rate on Jakarta Composite Index (JCI) and Jakarta Islamic Indeks (JII)'s. Internasional Research Journal of Business Studies, 173-182.

Ross, S. A. (1976). The Arbitrage Theory of Capital Asset Pricing. Journal of Economic Theory: Theory 13, 341-360.

Sugiarto, Danang. (2017). SahamCalon 'Pemilik' AirAsia Terus Melejit, Analis: Hati-Hati. Retrieved on 13 February 2019 from https://finance.detik.com/bursa-dan-valas/d-3627900/saham-calon-pemilikairasia-terus-melejit-analis-hati-hati 
Sukamulja, P. D. (2017). PengantarPermodelanKeuangandanAnalisisPasar Modal. Yogyakarta: CV. Andi Offset.

Suprayitno, Dede. (2018). Melantai di BEI, Saham AirAsia Terus Terbang. Retrieved on 13 February 2019 from https://ekonomi.kompas.com/read/2018/01/09/082527126/melantai-di-bei-sahamairasia-terus-terbang

Sinaga, Edwin. (2011). Garuda Indonesia, MasalahdanPeluangnya. Retrieved on 13 Februari 2019 from https://economy.okezone.com/read/2011/03/16/226/435327/garuda-indonesia-masalah-danpeluangnya

Sung, T. (1991). Stocks Return Volality in the Tokyo Stock Exchange. Japan and the World Economy Vol. 3, 285-298.

Utami, M. (1997). Perananprofitabilitas, sukubunga, inflasidannilaitukardalammempengaruhipasar modal Indonesia selamakrisisekonomi. JurnalManajemen\&Kewirausahaan, 5(2), 123-131.

Widiatmodjo, S. (2006). Cara SehatInvestasi di Pasar Modal. Jakarta: PT. Gramedia. 